\title{
PROPERTY RIGHTS IN THE POSTCOLONIAL WORLD
}

\author{
Richard de Schweinitz \\ Loyola University New Orleans, New Orleans, LA, USA \\ https://orcid.org/0000-0003-1233-289X
}

\author{
Walter E. Block \\ Loyola University New Orleans, New Orleans, LA, USA \\ https://orcid.org/0000-0003-2215-4791
}

CMESTE

JEL category: F54

\begin{abstract}
Private property rights are the key to economic development. They assist economic actors in forming reasonable expectations in their transactions with others and incentivize users of property to internalize the costs of their operations. However, in many cases, and especially in the case of land, private property rights must be carved out of preexisting communal property rights. Some enclosure of the commons, some divvying up of the common lot into private parcels is required. Doing so incurs vast administrative costs to appraise the value of the property and assign it to private individuals. Most often, the only apparatus capable of carrying out such a project is that institution that holds a monopoly on the use of force. Thus, major shifts in property rights regimes tend to be carried out by government bureaucracies. It is at this juncture that the historical development of property rights regimes between non-colonized and colonized societies is split. In non-colonized societies, the process of enclosure was carried out over long periods by domestic governments; but in colonized societies, the communal property was privatized all at once, and generally for the benefit of colonizers, not natives. The shock of imperialist violence creates an antipathy toward colonizers and, by extension, their economic regimes. Thus, when independence is achieved by colonized people and a new redistribution of property is required, the practice of privatization is maligned, and the collectivization of property is favored. However, such regimes reproduce the incentive structure of the commons, leading inevitably to the tragedy of underdevelopment.
\end{abstract}

Keywords: Property rights; colonialism; economic development.

\section{INTRODUCTION}

The question of economic development generally centers around a small set of key factors: resource richness, concentration of physical and human

Address of the corresponding author:

Richard de Schweinitz

莑" rgdeschw@my.loyno.edu capital, and property rights regimes. The former qualities are typically products of a country's particular endowment of resources. However, the development of property rights is often complicated by a vast array of historical and political contingencies. For underdeveloped countries, the legacy of colonialism is often deeply implicated in these questions. From the shaping of borders to the building of institutions that last into 
the present day to the political, social, and economic discourse that is undertaken within these institutions, the impact of a colonial past cannot be understated. In this paper, we trace the effects of colonialism on the development of property rights regimes within the postcolonial world.

\section{ANALYSIS}

Before discussing the actual process and difficulties of instituting property rights regimes, however, let us consider the nature of property rights themselves. Harold Demsetz (1967, p. 347) described property rights as an "instrument of society" which "derive their significance from the fact that they help a man form those expectations which he can reasonably hold in his dealings with others." (Demsetz, 1967, p. 348) In simple terms, property rights are basic terms of trade, a sort of 'rules of the game' that set the boundaries of negotiation. According to Demsetz, the extension of property rights into new areas of social life allows society to interact more smoothly, by giving actors a basis from which to make their economic calculus. When things can be reliably 'owned', economic actors are given a common referent to use in negotiating their value and use. Demsetz further argues that due to the shared understanding they allow for, property rights provide a useful avenue for entrepreneurs to internalize the externalities of their behavior.

To illustrate this, he offers the example of the development of the transition from serf to freeman, or from slave to free man: feudal lords, like slave owners, are not able to recognize all the costs of their operations, but if serfs or slaves are able to negotiate to purchase their freedom, market operations will allow the costs of serf or slave labor to be internalized. While illustrative of the value of property rights, this hypothetical describes only private property rights - but not all property rights are exclusively private. Property rights may be communal in their practice, which means that the property belongs in some form to all the members of a community, not just to an individual. Examples

1 Private versions of communal property rights include the nunnery, convent, kibbutz, commune, collective, syndicalist, cooperatives, monastery, abbey, priory, friary, religious community, family. of communal property include public parks or sidewalks, which are open for use by anyone. ${ }^{1}$ Often, communal property rights persist simply because, a) nobody has laid claim to the thing in question (for example, a field in the wilderness), or b) the transaction costs involved in the production of private property rights is too high (for example, a sidewalk utilized by many people, none of whom has a particular exclusionary claim over it). Communal property rights are a useful and natural form, so long as an individual does not need exclusive rights to the things held under them. ${ }^{2}$

However, if there is some reason an individual would need to exclude the public from free use of some property - for example, if a slave wanted exclusive claim over his or her own body - then negotiations for the establishment of private property rights would have to occur. It is for this reason that private property rights are a necessary aspect of social and especially economic life. If an entrepreneur could not forcibly exclude the community from freely reaping the benefits of his business, he would have no incentive to start a firm in the first place. Conversely - and this part is especially important - not only are private property rights conducive to the economic productivity of the property in question but their absence also often have the very opposite effect.

When a property is communally owned, each user of the property faces diffuse costs but concentrated benefits from its use. This often leads to the degradation of the property in question. The typical example of this phenomenon is known as the "tragedy of the commons". In English towns, there existed historically a patch of land set aside for common grazing. Because this land - known as the 'commons' - was open to all, anyone who chose to let his flock graze there was able to (potentially) reap all the benefits of the land, but would face only a fraction of the costs, roughly proportionate to the fraction of the population he represented. Unsurprisingly, the average grazer typically took more than his fair share, ultimately leading to the tragic deterioration of the

${ }^{2}$ For the case in favor of privatizing public parks, sidewalks, roads, streets, highways, see Block (2009). 
commons. ${ }^{3}$ The only solution to this problem, Demsetz suggests, is the establishment of private property rights over the land which was communally owned - which, historically, is exactly what happened. As Demsetz explains, "property rights arise when it becomes economic for those affected by externalities to internalize benefits and costs." (Demsetz, 1967, p. 354) In other words, individual actors will take it upon themselves to establish and, if necessary, to change property rights regimes whenever a property is being misused. Therefore, the ability of individuals to establish private property rights regimes is so important for economic development.

Unfortunately, in examining postcolonial economic development, it is at this juncture, the transition between property rights regimes, that the first long-term consequences of colonialism become apparent. Banner (2002) explains that communities seeking to establish new property rights regimes face two primary obstacles - the difficulty of mass collective action and high transition costs. Collective action is complicated by the effort needed for everyone to reassess and redistribute his property, and high transition costs can be found in the difficulties of "ascertaining the value of everyone's rights under the old system and locating equivalent rights under the new one." (Banner, 2002, p. 364) When left up solely to the will of scattered individuals, the challenge of overcoming these obstacles can often be insurmountable. Banner concludes that instead, one way for societies to solve this is to turn to the government to forcibly change property rights regimes. ${ }^{4}$ The force carried by government bureaucracies can overcome the obstacle of collective action - but the administrative costs of appraising all of the property affected by the regime change remain. Banner explains that to

${ }^{3}$ Ostrom (1990) mistakenly defends this system. For a critique of her views on this matter, see Block (2011A), Jankovic and Block (2016)

${ }^{4}$ Of course, there are the well-known problems of "government failure" that mitigate against any such "solution." See on this Buchanan and Tullock (1962)

${ }^{5}$ It all too often the case that, in fact, governments forcibly coopt movements for social change in order to maintain power - but for our purposes, the overcome this, "the managers of transitions had to cut some corners... [bureaucracies] had to adopt some rules of thumb that would drive the costs of valuation and assignment low enough to make transition feasible." (Banner, 2002, p. 368) These necessary rules of thumb inevitably ended up aligning with the values of the elite and influential.

In non-colonial states, benefits generally fell along the lines of nobility and peasantry; in colonial states, the colonists were the main beneficiaries. Banner gives the example of British authorities dividing up land into private plots in colonial New Zealand. As he explains: "Native Land Court judges fell into the habit of registering blocks of land to a maximum of 10 Maori, regardless of the true number of people with rights to resources within the block. This kind of corner-cutting no doubt served its twin purposes of curbing the cost of ascertaining the owners and facilitating land sales to British settlers by reducing the number of Maori with standing to object." (Banner, 2002, pp. 368-369) The dynamic Banner describes here is complex. Though societies need to establish private property rights regimes to develop economically, the difficulties of doing so mean that only government, with its exclusive right to force, can affect the necessary changes. ${ }^{5}$ In the case of a colonial holding, like New Zealand, gains from property regime transitions tend to be directed disproportionately towards colonial property owners and away from colonial subjects. ${ }^{6}$

Ault and Rutman (1979, p. 181) show that, contrary to the popular beliefs of colonizers, many tribal communities in Africa developed private property rights regimes independently of colonial influence. They explain that according to the typical colonial scholar, private property rights were seen as incompatible with the native 'customary law', or tribal law, that prevailed in

result, bureaucratically led transitions in property regimes, remains the same.

${ }^{6}$ But this does not mean that the colonial subjects, even though given only "the short end of the stick" compared to their overlords, do worse than in cases where there is no colonialism at all. See below on this. 
many communities in Africa. Customary law generally guarantees communal rights to all land - by then seen by liberal Europeans as an antiquated convention - leading many of the British scholars and administrators studying their new subjects to consider-customary law to be the primary economic obstacle for underdeveloped tribal societies. Some development economists saw the creation of private property rights as a positive aspect of the legacy of colonialism. Development economist Peter Bauer mentioned "The relative backwardness of areas with few foreign contacts..." (1972, p. 230.) ${ }^{7}$ However, as Ault and Rutman point out, "customary tribal law is a flexible code that responds to changing economic conditions." (Ault \& Rutman, 1979, p. 181) Just as Demsetz predicted, property rights regimes change when the economic incentives which surround them do - and, predictably, Ault and Rutman perceived exactly this. Customary ownership rights were only communal for as long as the supply of land exceeded the demand for it - but once disputes for control of land began to arise, individual rights to plots of land would then be formulated by proceedings in tribal courts. Of course, as in other societies, the development of private property rights in tribal Africa was not easy. Ault and Rutman identify three main obstacles: firstly, the dearth of written contracts, with many communities relying solely upon oral agreements, and secondly, the lack of predictability on the part of the courts (Ault \& Rutman, 1979, p. 176). The third is more complex; after the colonial period, once independent, self-governing states were formed, the development of private property rights was often shut down or even reverted by government institutions. (Ault \& Rutman, 1979, p. 178)

To review: societies tend toward the creation of private property rights, and when these rights are established by colonial governments, they tend to disadvantage colonial subjects for the benefit of colonists. This disadvantage (among many others) tracing from the colonial period may explain some aspects of the generational inequality that has lasted until the current postcolonial period. However, this is where a

7 Bauer, 1954, 1972, 1981, 1982, 1984, 1987; Bauer and Yamey, 1957 distinction between postcolonial countries must be made. In countries with significant populations descendant from both colonists and natives, such as New Zealand or South Africa, these inherited issues may continue to develop - but, once they have been set in place, rarely does the issue of property rights regimes resurface. Now consider those postcolonial territories which were more or less entirely vacated by colonizers. It is these countries that have seen the most conflict on the subject - and, coincidentally, it is these countries that are often the most direly underdeveloped. Many communities in these countries, despite possessing a high population and great potential for economic development, either maintain a traditional communal property rights regime or are stuck in some nebulous state in between. Many others, having had established private property rights during the colonial period, have, since independence, abolished it. Why is this? If Demsetz is correct in claiming that societies tend toward the establishment of private property rights, why have many postcolonial societies failed to do so, and even actively moved in the opposite direction? The answer lies in the historically contingent formational ideologies of the postcolonial state.

One such postcolonial ideology was the African Socialist ideology of Ujamaa conceived by Julius Nyerere, the first President of the newly independent Tanganyika/Tanzania. The basis of Ujamaa was the ideal of African self-reliance, a value which he saw as diametrically opposed to the notion of private property. (Bjerk, 2015, p. 104) Seen through the lens of a traditional economic theorist such as Demsetz, such a position seems confusing. How could individual rights to the property be seen as opposed to the notion of selfreliance? It is at this point where the legacy of colonialism sees its most sinister revival. Even after colonial powers have vacated their holdings, the societies they leave behind are still affected by the memory of their colonial past. The notion of private property - extricated from the historical context of the logical transfer from public to private in which Western thinkers like Demsetz understood it - came to the colonial subject not as a natural development, but as a sudden and 
forceful imposition. Free enterprise as a whole was associated with the imported ideology of colonizers, who came with the empire in one hand and capital in the other. Capitalism was therefore perceived as inseparable from imperialism and, by extension, exploitation, which tracked quite cleanly with the attractively anti-colonial ideology of socialism. After independence, state builders and politicians sought to distance themselves from anything that could be interpreted as colonial - so socialism was the most obvious route. It did not escape early postcolonial state builders that, like capitalism, socialism was a foreign ideology as well. To reconcile this, Nyerere formulated Ujamaa as natively African socialism, rooted in what he considered ancient African values, such as family, ancestry, and connection to the land (Bjerk, 2015, p. 101). Dispelling any notion that he might be carrying out some internalized paternalism, Nyerere declared, "We, in Africa, have no more need of being 'converted' to socialism than we have of being 'taught' democracy. Both are rooted in our own past." (Bjerk, 2015, p. 107) In the process of this national mythmaking, all memory of self-determined African private property rights is obliterated - and any postcolonial attempts at privatization can be accused of betraying true African values.

Ault and Rutman ascertained from their studies, "the failure of several independence leaders to recognize that the incipient forms of capitalism they observed were the results of changes in economic conditions rather than colonialism led some of them to attempt to reestablish communal land systems". (Ault \& Rutman, 1979, p. 181) Obviously, this interference with individual human action has not had a positive effect on the economy; they continue, "because this land tenure system is based upon ... conditions that no longer exist and is inherently unstable as land becomes scarce, incentives have created that lead to inefficient... and less than optimal investment in land and agriculture". (Ault \& Rutman, 1979, pp. 181-182) The process completes its revolution in a tragic full circle; the lingering influence of colonialism manages even to destroy the notions of individualism and economic liberty that lay at the center of its paternalistic motivations. By 1979, the economy of Tanzania, dominated by the ideology of Ujamaa since independence, was in dire straits; Nyerere's collectivized villages held $90 \%$ of the rural population but produced only $5 \%$ of the country's agricultural output. (Martin, 2005) Nyerere stepped down in 1985, giving the country over to structural adjustment under the IMF and the World Bank as it began to liberalize. Since privatization, the economy of Tanzania has been steadily improving. The country's GDP, as measured by the World Bank, rose from $\$ 5.1$ billion in 1988 to $\$ 9.3$ billion in 1998 , and then to $\$ 27.4$ billion in 2008. (The World Bank, 2017)

\section{CONCLUSIONS}

To have a functioning economy, a society requires some system of private property rights. Demsetz showed that this rights regime must exist to allow for the exclusionary ownership of property when it becomes profitable for individuals to internalize their benefits and costs. In practice, however, due to the towering administrative costs of inspiring collective action as well as the cost of appraising the value of all property and assigning it to private individuals, this also means that societies must have some apparatus in place for the establishment of these property rights. For most societies, this apparatus is found in the coercive power of government, and so property rights regime changes are carried out by government bureaucracies. In non-colonial societies, this regime change was carried out over time; but in colonial societies, it came all at once, and not as a natural development from within, but as an imposition from without. The inherent bias in bureaucracies leads them to appraise and assign property rights, by and large, to the powerful and privileged - which, in colonial societies, were colonizers, not natives. This, understandably, breeds in many colonized people great resentment towards colonizers and their political ideologies. Thus, when colonized people attain independence from their conquerors, in undertaking their reorganizations of property and policy, the establishment of private property regimes is not embraced, but instead avoided, and in many cases, reversed. Instead of carving communal property into private property, private property is collectivized into the communal property, leading inevitably into a state of underdevelopment. 


\section{WORKS CITED}

Ault, D., \& Rutman, G. (1979). The Development of Individual Rights to Property in Tribal Africa. The Journal of Law \& Economics, 22(1).

Banner, S. (2002). Transitions between Property Regimes. The Journal of Legal Studies, 31(S2).

Bauer, P. T. (1954[1967]). West African Trade. New York, N.Y.: Augustus M Kelley Pubs

Bauer, P. T. (1972). Dissent on Development. Cambridge, MA: Harvard University Press

Bauer, P. T. (1981). Equality, the Third World, and Economic Delusion. Cambridge: Harvard University Press

Bauer, P. T. (1982). Ecclesiastical Economics is Envy Exalted. This World, 1 (Winter/Spring).

Bauer, P. T. (1984). Reality and Rhetoric: Studies in the Economics of Development. Cambridge Mass.: Harvard University Press.

Bauer, P. T. (1987, Nov). Population Scares. Commentary, 84(5), 39-42

Bauer, P. T. (1991). The Development Frontier: Essays in Applied Economics. Harvester Wheatsheaf

Bauer, P. T., \& Yamey, B. S. (1957). The Economics of Under-developed Countries. The University of Chicago Press, Chicago, II.

Bjerk, P. (2015). Building a Peaceful Nation: Julius Nyerere and the Establishment of Sovereignty in Tanzania, 1960-1964. Rochester: University of Rochester Press.

Block, W. E. (2009). The Privatization of Roads and Highways: Human and Economic Factors. Auburn, AL: The Mises Institute.

Block, W. E. (2011A). Review essay of Ostrom, Elinor. 1990. Governing the commons: The evolution of institutions for collective action. Cambridge, UK and New York, NY: Cambridge University Press; in Libertarian Papers, 3, Art. 21; http://libertarianpapers.org/2011/21-block-review-of-ostromsgoverning-the-commons/

Buchanan, J. M., \& Tullock, G. (1962). The Calculus of Consent: Logical Foundations of Constitutional Democracy. Ann Arbor: University of Michigan.

Demsetz, H. (1967). Toward a Theory of Property Rights. The American Economic Review, 57(2), 347.

Jankovic, I., \& Block, W. E. (2016). Tragedy of the Partnership: A Critique of Elinor Ostrom. American Journal of Economics and Sociology, 75(2), 289-318. https://onlinelibrary.wiley.com/doi/10.1111/ajes.12141/full.

Martin, M. (2005). The Fate of Africa: From the Hopes of Freedom to the Heart of Despair. Nowy Jork: PublicAffairs.

Ostrom, E. (1990). Governing the Commons. Cambridge Press

The World Bank. (2017). Tanzania GDP. Washington, D.C.: The World Bank. Retrieved from https://data.worldbank.org/country/tanzania

Received for publication:

Revision received:

Accepted for publication:
22.01.2021

27.02.2021

06.07.2021 


\section{How to cite this article?}

Style - APA Sixth Edition:

Schweinitz, R. d., \& Block, W. E. (2021, July 15). Property rights in the postcolonial world. (Z. Cekerevac, Ed.) MEST Journal, 9(2), 68-74. doi:10.12709/mest.09.09.02.10

Style - Chicago Sixteenth Edition:

Schweinitz, Richard de, and Walter E. Block. 2021. "Property rights in the postcolonial world." Edited by Zoran Cekerevac. MEST Journal (MESTE) 9 (2): 68-74. doi:10.12709/mest.09.09.02.10.

Style - GOST Name Sort:

Schweinitz Richard de and Block Walter E. Property rights in the postcolonial world [Journal] // MEST Journal / ed. Cekerevac Zoran. - Belgrade - Toronto : MESTE, July 15, 2021. - 2 : Vol. 9. - pp. 68-74.

Style - Harvard Anglia:

Schweinitz, R. d. \& Block, W. E., 2021. Property rights in the postcolonial world. MEST Journal, 15 July, 9(2), pp. 68-74.

Style - ISO 690 Numerical Reference:

Property rights in the postcolonial world. Schweinitz, Richard de and Block, Walter E. [ed.] Zoran Cekerevac. 2, Belgrade - Toronto : MESTE, July 15, 2021, MEST Journal, Vol. 9, pp. 68-74. 